\title{
ORGANIZATIONAL AND LEGAL PRINCIPLES OF ACCOUNTING IN TRADE
}

\section{Oksana Dziuba ${ }^{1}$}

DOI: https://doi.org/10.30525/978-9934-588-15-0-27

Abstract. The study considers the features and basic organizational and legal principles of accounting in trade, information support for accounting organization. The relevance of this topic is that a large part of enterprises operating in the territory of Ukraine are engaged in trade activities. The purpose of the study is to summarize the theoretical bases and practical aspects of information support for the organization of activity and accounting of trade enterprises. Particular attention is paid to organizational forms of trading activities in a market economy, types of trading activities, such as wholesale and retail trade, restaurant industry, features of the licensing process of certain activities, state regulation of accounting and financial reporting in trade and restaurant management, namely in the system of management of trade enterprise and restaurant business, organizational forms of accounting, objects of accounting in trade and restaurant economy, material liability and its types, the role of accounting in the organization of trading activities. In the course of the research the following general scientific methods of cognition were used: observations and comparisons, which were used in the analysis of the organizational and legal conditions of trade activity, as well as methods of induction and deduction, combination of analysis and synthesis, historical and logical approaches, generalization. The research material defines the content of the basic concepts of the research topic, these categories are considered as opportunities to reveal the main features of the accounting process of generalization of information of trade enterprises. The features of organization of trading activity at the stage of creation of the enterprise are considered. The analysis of the use of accounting categories for trading is carried out in accordance with account-

\footnotetext{
${ }^{1}$ Candidate of Economic Sciences, Associate Professor, Associate Professor at Department of Accounting and Taxation, Vinnytsa Institute of Trade and Economics of Kyiv National University of Trade and Economics, Ukraine

(C) Oksana Dziuba
} 
ing and tax law. Special attention is paid to the organization of accounting at trade enterprises. The significance of the results of the study is as follows: the results of the study summarize the features and basic organizational and legal principles of accounting in trade, information support for accounting. in the current legal conditions and the nature of the impact of legislative changes on the financial status of the activity of economic entities; the method of organization of accounting in trade is generalized.

\section{Introduction}

A large part of economic entities operating in the territory of Ukraine are engaged in trading activities or in one way or another related to trading activities. The implementation of trading activities has its own peculiarities starting from the process of creation of the enterprise and in the process of activity. Legislative regulation and accounting of trade activities deserve special attention. The purpose of the study is to summarize the theoretical bases and practical aspects of information support for the organization of activity and accounting of trade enterprises.

Trading activity has always been different from other activities and had its own peculiarities, which significantly affects the accounting of trade enterprises, especially retail ones. At the present stage of development of retail trade there are significant changes in the structure of this sphere, which is connected with the emergence and active development of new formats of trade, the use of advanced sales technologies, modern logistics and information systems, as well as a wide range of related services. The theoretical problems, methods and organization of accounting of commodity operations of trading enterprises remain not fully worked out, which in turn influences the quality of information support of enterprise activity management. In recent years, there has been a tendency to increase competition, reduce profits and slow down the pace of market development. Due to the above, the managers of the trade enterprises are constantly searching for ways to increase the profitability of their activities. One such way is effective inventory management based on the formation of accounting information on commodity transactions. Therefore, special attention is needed to the organization of accounting of trade enterprises in the current economic conditions.

Analyzing the scientific contribution of domestic scientists, it should be noted that the scientific and methodological basis of organization of activ- 
ity and accounting of operations of trade enterprises does not fully satisfy the needs of management. In addition, it is not always adapted to modern trading formats.

\section{Legal prerequisites and types of trading activity in modern economic conditions}

Trading activity in Ukraine is by far one of the most common forms of entrepreneurship. Trade - any transaction carried out under contracts of sale, mines, deliveries and other civil contracts that involve the transfer of ownership of goods.

According to the Economic Code of Ukraine [1] economic and commercial is carried out by economic entities in the field of commodity circulation, aimed at the sale of products for industrial purposes and consumer goods, as well as ancillary activities that ensure their implementation through the provision of appropriate services.

Commercial activity is conducted by economic entities in the field of retail and wholesale trade, as well as the restaurant industry and is regulated by the Economic [1], Civil [2] and Tax [3] codes of Ukraine, the Law of Ukraine «On Consumer Protection» [4], conducting trade activities and rules for commercial servicing of the population [5], other normative legal acts.

According to the tax legislation, commercial activity is retail and wholesale trade, activity in the trade-production (restaurant) sphere for cash, other cash means of payment and with the use of payment cards.

The main terms for trading activity are given in the state standard of Ukraine 4303: 2004 «Retail and wholesale trade. Terms and definitions» [6] and the state standard of Ukraine 4281-2004 «Establishments of the restaurant industry. Classification» [7] according to which trading activity is an initiative, systematic, at-risk-of-profit-making activities of legal and natural persons for the purchase and sale of goods to end-users or intermediary operations, or activities for the provision of agency, representative, commission and other services in the promotion of goods moat from producer to consumer.

The definition of retail and restaurant business is given in the Instruction on filling in the forms of state statistical observations regarding the trade and restaurant network [8].

Retail trade - a type of economic activity of economic entities for sale (without processing) to the population of new and used goods, intended 
mainly for consumption by citizens (individuals) or households, in shops, department stores, benches and kiosks, parcel trade firms, trade intermediaries, etc. (codes according to the Classification of Economic Activities).

Restaurant business - a type of economic activity of business entities to provide services to meet the needs of consumers in catering with or without leisure in the establishments (facilities) of the restaurant industry.

Retail facility is a local unit (structural unit) of an economic entity in which consumer goods are sold directly to the public for personal consumption.

Restaurant establishment - a local unit (structural unit) of an entity that is housed in a separate building or premises, as a rule, is equipped with tables and chairs for the consumption of food hall and necessary industrial and domestic premises and in which it sells self-made and purchased goods, mainly for on-site consumption.

Restaurant business - a type of economic activity of business entities in providing services in relation to meeting the needs of consumers with or without leisure catering.

Restaurant establishment - organizational and structural unit in the restaurant industry, which performs production and trading activities: produces and (or) prepares, sells and organizes consumption of products of its own production and purchased goods, can organize leisure of consumers.

As mentioned above, commercial and restaurant activities are carried out by economic entities.

Business entity - a legal entity, registered in accordance with the procedure established by law, irrespective of its organizational and legal form, which conducts economic activity, except for the state and local self-government bodies, as well as an entrepreneur and an investor, foreign, which is a party to the product sharing agreement, its contractor, subcontractor, supplier and other counterparty, performing the work provided for in the product sharing agreement, based on investment agreements rum.

Legal conditions for conducting entrepreneurial activity, established by the state, require state registration of the business entity, confirming the recognition by the state of the lawfulness of the entity's entry into the business sphere. State registration is carried out in accordance with the Law of Ukraine «On State Registration of Legal Entities and Individual Entrepreneurs» [9].

The choice of the legal form of entrepreneurship is made independently. This should take into account the content and main areas of activity, the 
resources that can be used, the type of ownership, the number and composition of persons who are united to conduct business activities.

In the trade and restaurant business, you can work as an entrepreneur or as a legal entity.

A legal entity created to meet social and personal needs through the systematic implementation of industrial, research, trade, and other economic activities is recognized by the enterprise.

Depending on the method of formation (foundation) and formation of the statutory fund in Ukraine, different forms of partnership exist.

According to the Laws of Ukraine "On Business Companies" [10] and "On Joint-Stock Companies" [11], the following companies are: joint-stock companies, limited liability companies, additional liability companies, full partnerships, limited partnerships.

The constituent documents must contain information about the type of company, the subject and purpose of its activity, composition of founders and participants, name and location, size and procedure of formation of authorized (compound) capital, the procedure for distribution of profits and losses, composition and competence of the bodies of the company and the order of their decision making., including a list of issues requiring a qualified majority vote, the procedure for amending the constituent documents and the procedure for liquidation and reorganization of the company.

The company is considered established and acquires the rights of a legal entity from the date of its state registration in accordance with the procedure established by law.

State registration of companies is carried out in accordance with the procedure established by law for state registration of legal entities.

All enterprises, depending on the number of employees and the volume of product sales revenue per year, can be attributed to micro, small, medium or large enterprises.

A business entity in the trade and restaurant business may have:

- wholesale trade facilities, warehouse or warehouse network - for conducting wholesale trading activities;

- retail, retail trade network - for conducting retail trade activities;

- a network of restaurants (restaurants, cafes, cafeterias, etc.) - to provide restaurant services. 
Shopping facilities are:

1) in the sphere of wholesale trade: commodity warehouse (universal, specialized, mixed), store-warehouse;

2) in the sphere of retail trade

- shop, which can be: food, non-food, mixed (by product specialization); universal, specialized, highly specialized, combined, non-specialized (in product range); individual service, self-service, trade in samples, trade by order (by the method of sale of goods); pavilion; kiosk, yatka; tent; tray, chest; commodity warehouse; store-warehouse, store-warehouse.

The restaurant establishment is located in a specially designed and equipped room.

Type of restaurant establishment - a set of common characteristics of production and trade activities of the establishment.

The class of a restaurant establishment is a set of distinctive features of an establishment of a certain type, which characterizes the level of requirements for products of own production and purchased goods, conditions of their consumption, organization of services and leisure of consumers.

Types of restaurants: restaurants; bars; cafes, cafeterias; canteens, including canteens at enterprises, educational establishments, etc.; eateries; buffets, culinary shops; kitchens, billets.

Classes of restaurants and bars: first, highest, luxury.

The restaurant enterprise class chooses independently, considering the level of assortment, technical equipment, service (self-service, waiters, combined), aesthetic design, etc.

In the restaurant industry, it is possible to distinguish such economic processes as procurement, production, sale, consumption organization. The latter process is specific to this type of activity only. In addition to state registration, in the cases stipulated by the law, appropriate permits must be obtained.

\section{Licensing and certification as a prerequisite for organizing trading activities}

The procedure for organizing and conducting trade activities in Ukraine provides for the fulfillment by economic entities of certain requirements and norms established by the current legislation. These requirements and norms 
depend on many factors: the type of goods, places and forms of trade, the order of payment with buyers, etc. One such requirement is licensing. The licensing procedure is enshrined in the Law of Ukraine "On Licensing of Economic Activities" [12].

License - a document of the state model, which certifies the right of the licensee to carry out the type of economic activity specified in it within the specified period in case of its establishment by the Cabinet of Ministers of Ukraine subject to the fulfillment of the license conditions;

Licensing - Issuing, reissuing and revoking licenses, issuing duplicate licenses, maintaining licensing cases and licensing registers, controlling compliance with license terms by licensees, issuing orders to eliminate violations of licensing conditions, as well as orders to eliminate violations of laws and regulations.

In the field of trade, according to the legislation, the following are licensed:

- production and sale of alcohol ethyl, cognac and fruit, alcoholic beverages and tobacco;

- retail trade in veterinary medicines and preparations;

- trade in pesticides and agrochemicals (only plant growth regulators);

- production of special means charged with tear and irritant substances, personal protection, active defense and their sale;

- development, production of special technical means for removal of information from communication channels, other means of silent acquisition of information, trade in special technical means for removal of information from communication channels, other means of silent receipt of information;

- providing services in the field of cryptographic information security (except for digital signature services), trading of cryptosystems and cryptographic information security facilities;

- trade in breeding (genetic) resources, conducting genetic examination of the origin and anomalies of animals;

- activities related to the production, trade in pyrotechnics;

- trade in biomass and biogas liquid fuels.

An entity that intends to carry out a certain type of business activity that is licensed, either individually or through an authorized body or person, applies to the relevant licensing authority with an application for a specimen license. 
The license application must include the following information:

1) information about the applicant entity:

- name, location, bank details, identification code - for the legal entity;

- surname, name, patronymic, passport data (series, passport number, by whom and when issued, place of residence), identification number of the natural person - taxpayer and other obligatory payments - for the natural person;

2) type of economic activity.

The application for the license and the documents attached thereto shall be accepted by the description, a copy of which shall be issued to the applicant stating the date of acceptance of the documents by the licensing authority and the signature of the responsible person.

The licensing authority must issue the license no later than three working days from the date of receipt of the document confirming payment of the license.

The licensing authority shall make a note of the date of receipt of the documents confirming the applicant's payment for the license, on a copy of the description given to the applicant upon receipt of the license application.

If, within thirty calendar days of sending the license decision, the applicant has not submitted a document confirming the payment of the license or has not applied to the licensing authority to obtain a license, the licensing authority which issued the license shall have the right to cancel a decision to grant a license or to make a decision to invalidate such a license.

A copy of the license certified by the licensing authority shall be issued to the licensee - legal entity for each branch, another separate unit where the respective licensee will carry out the type of economic activity specified in the license, and confirm the licensee's right to such activity, and the licensee to the individual for the individual place of business activities.

Issuing a copy of the license is subject to a fee of one non-taxable minimum income. The license fee is credited to the State Budget of Ukraine.

In case of termination of carrying out the type of economic activity specified in the license at the place of carrying out such activity to which a copy of the license was issued, the licensee shall be obliged to inform the licensing authority in writing within ten working days from the date of termination. The licensing authority must make the appropriate changes to the licensing register no later than the next business day from the date of receipt of such notification. 
If the licensee intends to carry out the type of economic activity specified in the license after the expiration of its term of validity, if such term is set by the Cabinet of Ministers of Ukraine, it must obtain a new license.

A licensee may not transfer a license or a copy thereof to another legal or natural person for the purpose of conducting business activities.

For the issuance of a license, a fee shall be charged, the amount and procedure of crediting to which shall be established by the Cabinet of Ministers of Ukraine.

Certification is a procedure for verifying that a result of a production activity, product, or service is a regulatory requirement, whereby a third party documents that the product, work (process), or service meets the specified requirements.

During certification and in the case of a positive decision of the certification body, the applicant is issued a certificate and the right to mark the products with a special mark of conformity (The form, dimensions and technical requirements for the mark of conformity are determined by the state standard).

A certificate of conformity is a document issued in accordance with the rules of a certification system that states that a product, process, or service meets the requirements specified in the standards or other documents that set requirements for them.

It should be noted that the object of certification (products, process, service, etc.) must be identified, that is, the certification can be subject to this particular object and no other, in particular, derived from it or completely falsified. Conformity mark (certification mark) - a mark protected by law (combination of letters, numbers, graphic symbols, etc.), is used in accordance with the accepted rules of the certification system and indicates that a product, process or service meets specific standards or other regulatory documents that set requirements for them.

The certificate is a document confirming that the products are of high quality and meet the standards in force in Ukraine. Certificate of Conformity is an indicator of quality, above all for the consumer.

Compulsory certification (confirmation of conformity) is performed in accordance with the requirements of normative documents defined by Ukrainian legislation or regulatory documents, included in the List of products subject to mandatory certification in Ukraine, which is approved by the Central Executive Body for technical regulation. 
The conformity of products (goods) imported and sold in the territory of Ukraine to the standards in force in Ukraine must be confirmed by a certificate of conformity or a certificate of conformity, issued or recognized by a central executive body for technical regulation or accredited in accordance with the established certification body who is authorized to carry out this activity.

The inclusion of certified products in the Unified Register of Ukrainian certified products is carried out on the basis of:

1. Declarations of conformity issued by the manufacturer for each batch of foodstuffs, food raw materials, related materials, etc.

2. Certificates of conformity or certificates of conformity.

Voluntary certification of products is carried out by authorized certification bodies - enterprises, institutions and organizations in order to:

- prevention of the sale of products that endanger the life, health and property of citizens and the environment;

- assisting the consumer in the competent choice of products;

- creation of conditions for participation of business entities in international economic, scientific and technical cooperation and international trade.

There are two main steps to the certification process:

1. Research of production and production with registration of the corresponding acts and protocols in the accredited laboratory.

2. Granting on its basis the certificate by the state certification body.

There is a special feature: if products subject to certification are required to obtain a sanitary-epidemiological conclusion (hygiene conclusion), a quarantine permit or a veterinary certificate, the certificate can be obtained only after submission of all the above documents.

According to the Law of Ukraine «On the use of registrars of settlement operations in the sphere of trade, catering and services» [13] by legal entities (their branches, branches, and other separate subdivisions), as well as by natural persons - economic entities that carry out cash and non-cash settlement operations (with the use of payment cards, payment checks, tokens, etc.) in the sale of goods (provision of services), in the field of trade, restaurant business and services, as well as authorized persons banks and business entities performing foreign currency transactions should use the Transaction Registers. 
Payments for goods sold and services rendered may be made in cash and / or in non-cash form (using payment cards, payment checks, tokens, etc.) in accordance with the law. Together with the goods, the consumer is obliged to issue a settlement document of the established form for the full amount of the transaction, which certifies the fact of purchase of the goods and / or rendering of the service.

In a restaurant establishment where the service is provided by waiters, payment is made directly to the waiter in accordance with the invoice written on the prescribed form. After the calculation, the waiter issues the customer with a payment document (cash receipt, payment receipt).

One of the prerequisites for trading and restaurant business is accounting. The legal principles of regulation, organization, accounting and preparation of financial statements are set out in the Law of Ukraine «On Accounting and Financial Reporting in Ukraine» [14].

\section{Features of accounting and pricing of trade enterprises}

Accounting at the enterprise is maintained continuously from the date of registration of the enterprise until its liquidation.

Issues of organization of accounting at the enterprise are within the competence of its owner (owners) or authorized body (official) in accordance with the legislation and constituent documents.

The responsibility for the organization of accounting and ensuring the recording of all economic transactions in the primary documents, the preservation of the processed documents, registers and reporting within a specified period, but not less than three years, rests with the owner (s) or the authorized body (official), which executes the management by the company in accordance with the legislation and constituent documents.

Accounting is based on the basic principles of accounting. Accounting principles are the basic concepts underlying the accounting and reporting of an entity's business, its assets, liabilities, expenses, income, equity and financial results.

In accordance with the Law of Ukraine «On Accounting and Financial Reporting in Ukraine» the company was given the opportunity to choose one of four forms of accounting organization independently:

1. Introduction into the staff of the company as an accountant or the creation of an accounting service led by the chief accountant. 
2. Use of the services of an accounting specialist registered as an entrepreneur without creating a legal entity.

3. Contractual accounting on a centralized accounting or auditing firm.

4. Independent accounting and reporting directly to the owner or manager of the enterprise

A sound choice of one of the four organizational forms of accounting is essential for the enterprise.

The enterprise also selects the accounting form, taking into account the peculiarities of its activity and the technology of processing the accounting data; determines the accounting policy of the enterprise; develops a system and forms of management accounting; approves the inoculation document.

The most common forms of accounting in modern conditions - journal-warrant, memorial-warrant (chess-check), magazine-main, simplified, computer (tabular-dialog, or tabular-automated).

A simplified form of accounting using property registers is used by small businesses that carry out 100 to 300 business transactions per month.

An accounting policy is a set of principles, methods and procedures used by an entity to prepare and submit financial statements.

The accounting policy adopted by the enterprise is subject to registration with the relevant administrative document (order, order) of the enterprise, which is a document of internal use.

The Ministry of Finance of Ukraine lists the main accounting elements that must be disclosed in the accounting policy order. The accounting policy of the enterprise, in particular, the enterprises of the auction and the restaurant economy should specify the application of:

- methods of estimating the disposal of stocks;

- the frequency of determining the average cost of a unit of inventory;

- the accounting procedure (identified or overall) and the allocation of transport and procurement costs;

- separate subaccount of accounting of transport and procurement costs;

- methods of depreciation of fixed assets;

- value attributes of items that are part of low value non-current tangible assets;

- Class 8 and / or 9 of the Accounting Account Plan;

- the periodicity (period) of transferring the revaluation of non-current assets to retained earnings; 
- the method of calculating the doubtful debt reserve;

- a list of collateral created for future expenses and payments;

- the procedure for assessing the degree of completion of service operations;

- segments, priority type of segment, pricing principles in domestic calculations;

- the list and composition of variable and fixed overhead costs, the basis of their distribution;

- the list and composition of articles of calculation of production cost of production (works, services);

- the procedure for determining the degree of completion of works under a construction contract;

- to determine the financial assets acquired as a result of systematic operations;

- bases of distribution of expenses on transactions with equity instruments;

- materiality threshold for individual accounting entities;

- revaluation of fixed assets;

- the frequency with which deferred tax assets and deferred tax liabilities are reflected;

- a separate balance sheet by branches, representative offices, branches and other separate divisions of the enterprise.

Based on the principle of consistency, the accounting policies of an enterprise should provide for the continued (year to year) application of sound accounting policies adopted. Accounting policies can only change if the statutory requirements change at the enterprise, if the requirements of the body that performs the functions of government regulating accounting methodology and financial statements change, or if changes in accounting policies will provide a more accurate reflection of events (business transactions) in accounting and financial reporting.

The accounting policies of the enterprise and its changes are disclosed in the notes to the annual financial statements in a descriptive form or by enclosing a copy of the regulatory document establishing and changing accounting policies.

The detailing of accounting elements in an accounting policy order facilitates the work of accounting staff as it provides detailed guidance on the organization and accounting of trade and restaurant businesses. 
Particular attention is given to the valuation of trade accounting policies in the form of accounting policies in trade.

According to accounting standard «Inventories» [15], the valuation of goods in current accounting is based on their original value, which varies with the sources of income.

Purchased goods are credited to the balance sheet at cost. The cost of goods purchased for consideration is the cost of inventories, which consists of the following actual costs:

- amounts payable under the contract to the supplier (seller) less indirect taxes;

- the amount of import duty;

- amounts of indirect taxes in connection with the acquisition of inventories that are not recoverable to the enterprise;

- transportation and procurement costs (costs of stockpiling, payment of tariffs (freight) for handling and transportation of stocks by all means of transport to their place of use, including costs for insurance of risks of transportation of stocks). The amount of transportation and procurement costs that are aggregated on a separate subaccount of the inventory account is distributed monthly between the amount of inventory remaining at the end of the reporting month and the amount of inventories disposed of (used, sold, transferred free of charge, etc.) during the reporting month. The amount of transport and procurement costs attributable to disposing inventories is defined as the product of the average percentage of transport and procurement costs and the value of disposable inventories, which is reflected in the same accounting accounts in correspondence with which disposals of those inventories are recorded. The average percentage of transportation and procurement costs is determined by dividing the amount of balances of transportation and procurement costs at the beginning of the reporting month and transportation and procurement costs for the reporting month by the amount of inventories at the beginning of the month and inventories received during the reporting month.

- other costs directly attributable to the acquisition of the inventory and bringing it to a condition in which it is fit for use for its intended purpose. Such costs include, in particular, direct material costs, direct labor costs, other direct costs of the enterprise to refine and improve the quality of technical characteristics of inventories. 
The initial value of the goods included in the authorized capital of the enterprise is recognized by the founders (participants) of the enterprise as their fair value.

The fair value of the goods obtained free of charge by the enterprise is recognized.

The initial cost of goods acquired as a result of an exchange for such inventories is equal to the carrying amount of the inventories transferred. If the carrying amount of the inventories transferred exceeds their fair value, the original cost of the inventories received is their fair value. The difference between the carrying amount and the fair value of the inventories transferred is included in the expenses of the reporting period.

The fair value of the inventories acquired is recognized at the initial cost of the goods purchased in exchange for dissimilar inventories.

They are not included in the original cost of the goods but are attributable to the costs of the period in which they were made (established): overtime losses and inventory shortages; financial expenses (except financial expenses that are included in the cost of qualifying assets in accordance with Accounting Standard 31) «Financial expenses», sales expenses; general and other similar expenses not directly related to the acquisition and delivery of inventories and bringing them to a state where they are fit for use for the intended purpose.

Another element of the accounting policy of a trading company is the valuation of goods at disposal. In accordance with P (C) BO 9, the following methods are used to estimate inventories at disposal:

- the identified cost of the relevant unit of inventory;

- weighted average cost;

- the cost of the first on-time inventory (FIFO);

- regulatory costs;

- selling prices.

As a rule, the following methods of estimating the disposal of inventories are used by trade and restaurant businesses: weighted average cost, prime cost of inventories (FIFO) and sale prices.

The weighted average cost is calculated for each unit of inventory by dividing the total value of the balance of such inventories at the beginning of the reporting month and the value of inventories received in the reporting month by the total number of inventories at the beginning of the reporting month and inventories received in the reporting month. 
The valuation of FIFO inventories is based on the assumption that inventories are used in the order in which they are received by the enterprise (recorded in accounting), that is, inventories that are the first to be released into production (sale and other disposal) are valued at cost first. stock inflows.

The estimate of sales prices is based on the use by the retailers of the average percentage of the trade margin of the goods. This method may be applied (unless other methods of estimating the disposal of inventories are not justified) to undertakings with significant and variable product nomenclature with approximately the same level of trade margin. Cost of goods sold is defined as the difference between the sale (retail) value of goods sold and the amount of the trade margin for these goods. The amount of trade margin on goods sold is defined as the product of the sale (retail) value of goods sold and the average percentage of the trade margin. The average percentage of the trade mark-up is determined by dividing the amount of the trade mark-up balance at the beginning of the reporting month and the mark-up in the selling value of goods received in the reporting month by the amount of the sale (retail) value of the balance of goods at the beginning of the reporting month and the selling (retail) value in the received month. The method of valuation of goods at selling prices is used for retailers and restaurants, with a constant percentage of trade margin, to reduce the complexity of accounting procedures, simplify the inventory procedure and control the sale of goods at a price lower than the cost.

The efficiency of trade and restaurant business is influenced by the choice of the right pricing policy.

To date, there is no single universal formula for pricing. Each enterprise chooses its approach to pricing, the main normative document that regulates pricing policy, the procedure for setting and applying prices, the authority of state and local governments to set and regulate prices, and the organization of control over prices and tariffs in Ukraine, is the Law of Ukraine «On Prices and Pricing» [16]. In general, price is the monetary value of a unit of commodity.

Currently, the seller is free to determine the price of products, goods and services, except when the state interferes with the pricing process. 
Article 10 of the Economic Code of Ukraine establishes that the price policy of the state is one of the main directions of the economic policy of the state and aims at regulating the relations of exchange between market entities in order to ensure equivalence in the process of selling the national product, maintaining the necessary price parity between industries and types of economic activity, as well as ensuring the stability of wholesale and retail prices [1].

In trade, as in other branches of the national economy, free prices and state regulated prices apply.

Free prices are set by the entities independently on the consent of the parties for all goods, except for those subject to state regulation of prices. The free price in trade consists of the initial value, regardless of the source of origin (supplier, founder, barter) and trade margin.

Trade allowance (mark-up) is the amount of an entity's costs associated with the turnover of a product and incurs in the course of its retail sale and profit. The marginal trade mark-up (margin) is its maximum permissible level, which must be taken into account by the entity when selling the product in retail trade;

Prices for goods intended for sale on the domestic market of Ukraine shall be set exclusively in the currency of Ukraine, unless otherwise provided by international agreements ratified by Ukraine and by resolutions of the Cabinet of Ministers of Ukraine.

State regulated prices are imposed on goods that have a decisive influence on the overall level and dynamics of prices, have significant social significance, as well as on products produced by entities that hold a monopoly (dominant) position in the market.

Government regulated prices may be imposed on goods of economic entities that violate the requirements of the legislation on protection of economic competition.

Supply Fee (Supplier Fee) - The amount of an entity's costs associated with the turnover of a product and incurs in the course of its sale (sale) when it arrives from the manufacturer (supplier) to the relevant commodity market, and profits. The marginal cost of supply is its maximum level, which must be taken into account by the wholesaler when setting the price of the goods.

In trade there are certain types of prices: retail price, selling price, wholesale price. 


\section{Conclusions}

Trading activity occupies a significant place among the volumes of activity of domestic enterprises of various types of activity. When setting up a trading company, significant legislative and accounting features should be taken into account, including organizational forms of trading activities, types of trading activities, namely wholesale and retail trade, restaurant business, features of the licensing process for certain activities, state regulation of accounting and financial reporting in trade, and restaurant business. The research material defines the content of the basic concepts of the research topic, these categories are considered as opportunities to reveal the main features of the accounting process of generalization of information of trade enterprises. The features of organization of trading activity at the stage of creation of the enterprise are considered. The analysis of the use of accounting categories for trading is carried out in accordance with accounting and tax law. Special attention is paid to the organization of accounting at trade enterprises.

The significance of the results of the study is as follows: the results of the study summarize the features and basic organizational and legal principles of accounting in trade, information support for accounting. in the current legal conditions and the nature of the impact of legislative changes on the financial status of the activity of economic entities; the method of organization of accounting in trade is generalized.

\section{References:}

1. Commercial Code of Ukraine dated 16.01.2003 № 436-IV. URL: https:// zakon.rada.gov.ua/laws/show/436-15 (accessed 20.10.2019).

2. Civil Code of Ukraine dated 16.01.2003 № 435-IV. URL: https://zakon.rada. gov.ua/laws/show/435-15 (accessed 20.10.2019).

3. The Tax Code of Ukraine dated 02.12.2010 № 2755-VI. URL: https://zakon. rada.gov.ua/laws/show/2755-17 (accessed 20.10.2019).

4. Consumer protection: Law of Ukraine of May 12, 1991 No. 1023-XII. URL: https://zakon.rada.gov.ua/laws/show/1023-12 (accessed 20.10.2019).

5. On approval of the procedure for conducting trade activities and rules for retail trade services: Resolution of the Cabinet of Ministers of Ukraine; dated 15.06.2006 № 833. URL: https://zakon.rada.gov.ua/laws/show/833-2006-p (accessed 20.10.2019).

6. National Standard of Ukraine DSTU 4303: 2004 «Retail and Wholesale Trade. Terms and Definitions»: Order of the State Committee of Ukraine for Technical Regulation and Consumer Policy dated July 5, 2004. No. 130. URL: https://interbuh.com.ua/en/documents/oneregulations/11687 (accessed 21.10.2019). 
7. National Standard of Ukraine DSTU 4281-2004 «Restaurant Facilities. Classification»: Order of the State Committee of Ukraine for Technical Regulation and Consumer Policy of March 31, 2004 No. 59. URL: https://www.tic.in.ua/?page id $=8325 \&$ lang $=$ en $($ accessed 10.21.2019).

8. On approval of the Instruction on filling in the forms of state statistical observations regarding the trade and restaurant network: Order of the State Statistics Committee of Ukraine dated October 24, 2005 No. 327. URL: https://zakon.rada. gov.ua/laws/show/z1350- 05 (accessed 21.10.2019).

9. On State Registration of Legal Entities and Individual Entrepreneurs: Law of Ukraine of May 15, 2003 No. 755-IV. URL: https://zakon.rada.gov.ua/laws/ show/755-15. (accessed 21.10.2019).

10. On Business Companies: Law of Ukraine of September 19, 1991 No. 1576XII. URL: https://zakon.rada.gov.ua/laws/show/1576-12. (accessed 21.10.2019).

11. On Joint-Stock Companies: Law of Ukraine of 17.09.2008 No. 514-VI. URL: https://zakon2.rada.gov.ua/laws/show/514-17 (accessed 22.10.2019).

12. On licensing of economic activities: Law of Ukraine of 02.03.2015 No. 222VIII. URL: https://zakon.rada.gov.ua/laws/show/222-19 (accessed 22.10.2019).

13. On the use of registrars of settlement transactions in the sphere of trade, catering and services: Law of Ukraine of 06.07.1995 № 265/95-BP. URL: https:// zakon.rada.gov.ua/laws/show/265/95-vr (accessed 22.10.2019).

14. On accounting and financial reporting in Ukraine: Law of Ukraine of July 16, 1999 No. 996-XIV. URL: https://zakon.rada.gov.ua/laws/show/996-14 (accessed 23.10.2019).

15. On Approval of Regulation (Standard) of Accounting 9 «Inventories»: Order of the Ministry of Finance of Ukraine dated 24.10.99 № 246. URL: https:// zakon.rada.gov.ua/laws/show/z0751-99 (accessed 10.23.2019).

16. On prices and pricing: Law of Ukraine of 21.06.2012 No. 5007-VI. URL: https://zakon.rada.gov.ua/laws/show/5007-17 (accessed 23.10.2019). 